Bentham open
CrossMark
Content list available at: www.benthamopen.com/TOMCJ/
DOI: $10.2174 / 1874104501812010023$

REVIEW ARTICLE

\title{
Pharmacognostical Sources of Popular Medicine To Treat Alzheimer's Disease
}

Huba Kalász ${ }^{1, *}$, Shreesh Ojha ${ }^{2}$, Kornélia Tekes ${ }^{3}$, Éva Szőke ${ }^{4}$, Rajesh Mohanraj $^{2}$, Mohamed Fahim $^{5}$, Ernest Adeghate ${ }^{1}$ and Abdu Adem ${ }^{6}$

${ }^{I}$ Department of Pharmacology and Pharmacotherapy, Semmelweis University, Nagyvárad tér 4, Budapest, Hungary

${ }^{2}$ Department of Pharmacology and Therapeutics, College of Medicine and Health Sciences, United Arab Emirates University, P.O.Box 17666, Al-Ain, United Arab Emirates

${ }^{3}$ Department of Pharmacodynamics, Semmelweis University, 1089 Budapest, Nagyvárad tér 4, Hungary

${ }^{4}$ Department of Pharmacognosy, Semmelweis University, 1085 Budapest, Üllöi út 26, Hungary

${ }^{5}$ Department of Physiology, College of Medicine and Health Sciences, United Arab Emirates University

${ }^{6}$ Department of Pharmacology and Therapeutics, College of Medicine and Health Sciences, United Arab Emirates University, P.O.Box 17666, Al-Ain, United Arab Emirates

Received: November 1, 2017

Revised: January 21, 2018

Accepted: January 29, 2018

\section{Abstract:}

\section{Background:}

A large number of classical and recently discovered plants are indicated in preventing and/or treating Alzheimer's disease (AD).

\section{Objective:}

Name of plants with their anti-AD effects are important for their further use and investigation.

\section{Method:}

A short overview of AD is given; anti-Alzheimer plants are given in a Table.

Results:

Various medicinal plants are listed here as sources of popular medicines to be used in cases when patients are afraid of developing and/or suffer from AD. Some of these plants have been used for centuries. The major sources in the literature, over one hundred of references are given for plants that show beneficial effect on the progress of AD.

\section{Conclusion:}

Plant extracts are widely used addition to the synthetic drugs approved by various administrative authorities to stop/slow down the progress of symptoms of AD.

Keywords: Alzheimer's disease, Anti-AD effect, Etiopathogenesis, Amyloid fibers, Medicinal plants, Galantamine.

\section{INTRODUCTION}

Currently, Alzheimer's disease (AD) is one of the leading, neuro-degenerative diseases most commonly affecting people over 65 [1]. Its etiopathogenesis is still shrouded in mystery. Since the description of AD, several landmark

\footnotetext{
* Address correspondence to this authors at the Department of Pharmacology and Pharmacotherapy, Semmelweis University, Nagyvárad tér 4, Budapest, Hungary, Tel: +36-30-274-7486, Fax: +36-1-210-4416; E-mail: drkalasz@gmail.com
} 
discoveries pertaining to the pathogenesis of $\mathrm{AD}$ have been postulated. The major findings include the definition of hallmark events such as formation and accumulation of amyloid fibers, and over the years, it has become evident that defective protein processing is involved in AD [2]. The earlier notion was that the onset of AD could present itself years before the establishment of diagnosis, while unambiguous pathological events such as protein misfolding/aggregation could occur at later stages of the progress of the disease. However, after several landmark studies, numerous pathomechanisms have been postulated concerning the development of $\mathrm{AD}$, besides the identification its biomarkers [3]. It is now evident that vascular and metabolic syndromes/dysfunctions, could also play part in AD. In particular, inflammation, oxidative stress and endothelial dysfunction are now believed to promote the development of AD. The involvement of metabolic perturbations in the development of AD was braced by clinical epidemiological studies [4] and was proved to associate with diseases such as diabetes mellitus, dyslipidemia, hypertension, obesity, wherein oxidative stress and insulin resistance were enhanced [5]. Given the complex interplay of cellular signaling and nexus with metabolic diseases, several efforts have been directed to the identification of therapeutic targets/approach to combat AD. Genetic, pharmacological and cell biological studies continue to unravel the possibility of targeting the effector molecules, pathways of inflammation and oxidative stress. Plants have been confirmed to be essential agents in maintaining general well-being for everyone and their importance in the human diet has been unquestioned in modern science [6]. Furthermore, medicinal plants provide a myriad of biologically active molecules and these have been utilized in medicine for thousands of years. The utilization of these special plants and herbs marked the dawn of discovery in the area of pharmacologically active ligands [7]. Neurodegenerative disorders like AD itself are currently a therapeutic enigma with huge socioeconomic impact on improved life expectancy due to advancement in health care. Although the pathological and clinical aspects of these incapacitating disorders are explored to a certain extent, still the treatments applied these days provide only symptomatic relief with no improvement concerning the course or delay in the progression of the disease in question.

An increasing number of herbal extracts, poly-herbal and herbo-mineral preparations and phytochemicals obtained from herbs have been studied for their neuroprotective potential in AD for the past decade. These above mentioned studies have supplied us with utilizable new drug therapies based on medicinal plants.

\section{METHODS}

This review gives an overview of beneficial in vitro and in vivo adaptation of various plant extracts in $\mathrm{AD}$. The therapeutic potential and postulated ways of action of these agents have been thoroughly examined in multiple experiments in earlier reviews [8,9]. Recent reviews have focused on the therapeutic potential of traditional medicinal plants and their active components obtained from Chinese herbs for AD and cognitive impairment [10]. As neurofibrillary tangles and amyloid plaques are characterized by deficiency in cholinergic transmission in the basal forebrain, the inhibitors of the enzyme involved in the synthesis of acetylcholine (ACh). The first clinically approved and available AChE inhibitor was tacrine, however, from 2013 onwards it was discontinued in the USA. Nowadays, donepezil and rivastigmine are used in the treatment of AD. Recently, galantamine, an alkaloid obtained from plants of the Amaryllis family, has been developed. Currently, there are still ongoing clinical trials for galantamine. However, approved by the FDA, it is already used for the treatment of mild to moderate AD.

Encouraged by the success of galantamine, several medicinal plants and phytochemicals have been evaluated for the inhibitory effect against acetylcholine esterase enzyme (AChE) in both in vitro and in vivo models of AD.

A variety of plants reported to show inhibition of $\mathrm{AChE}$, may be considered promising for the treatment of $\mathrm{AD}$ associated cognitive decline [11]. Given the clustering of multiple factors involved in the pathogenesis of AD, new therapeutic targets have been selected to develop novel drugs and manage the multiple complications occurring along with AD.

Traditional medicines are being rediscovered for the fulfilment of a strategy aimed at the treatment. Recently, several targets including antioxidants, anti-inflammatory antiapoptotic, neurotrophic and antiamyloid/genesis drugs have been explored in the in vitro and in vivo models of AD. Naturally occurring dietary polyphenol compounds such as curcumin, resveratrol and green tea catechins have received considerable attention as attractive candidates for AD therapy. These polyphenolic compounds have been demonstrated to prevent AD due to their antioxidant, antiinflammatory, antiamyloidogenic effects and activating cellular stress adaptive to responses called "neurohormesis" process [12]. The safety and efficacy of herbal medicines as either monotherapy or adjunct to conventional medicines such as cholinesterase inhibitors and nootropic agents for AD have been reviewed based on data from sixteen randomised clinical trials [13]. Fifteen out of the 16 trials provided evidence for the efficacy of herbal medicines in the 
treatment of AD. Ginkgo biloba extract Egb761 has been the most frequently studied. Huperzine A, a cholinesterase inhibitor from Huperzia serrata has also been demonstrated to be effective against AD. Based on the systemic review of clinical studies, herbal medicines are believed to be effective and safe medicines for AD treatment.

In this view finding for new compounds effective enough to act on various biochemical targets having new action and low toxicity are requirements hard to meet for both scientists and the pharmaceutical industry. On the other hand, the need to find remedies for this crippling disease has resulted in the reviving interest in natural chemistry. Active constituents of plants, long-known herbs and their extracts may lead to the discovery of medicines successfully used for the treatment of $\mathrm{AD}$. It is generally believed that research on natural product chemistry has a large number of unexploited values capable of providing new possibilities in the treatment of AD.

In this paper, we treat mechanisms that might underlie the improvements in cognitive abilities, neurovascular functions and protection of nerve cells.

\section{RESULTS AND DISCUSSION}

The complete scientific name of the medicinal plants, the possible mechanism(s) of action and relevant references can be found in Table (1). A number of medicinal plants, used in Chinese, Ayurvedic, Tibetan, Oriental and Kampo medicines have a reputation enhancing cognitive functions.

Table 1. Medicinal plants exhibiting protection from Alzheimer's disease.

\begin{tabular}{|c|c|c|c|}
\hline No. & Medicinal Plants, Name and (Family) & Mechanism of Action & References \\
\hline 1. & $\begin{array}{l}\text { Abies koreana } \text { E.H. Wilson } \\
\text { (Pinaceae) }\end{array}$ & Improves the memory in scopolamine model of $\mathrm{AD}$ in mice. & {$[23]$} \\
\hline 2. & $\begin{array}{l}\text { Acorus gramineu Sol. } \\
\quad \text { (Acoraceae) }\end{array}$ & $\begin{array}{c}\text { Exerts AChE inhibitory and antioxidant activity. } \\
\text { Increases the learning and memory ability in rat model of AD. }\end{array}$ & {$[24,25]$} \\
\hline 3. & $\begin{array}{l}\text { Avicennia officinalis L. } \\
\text { (Acanthaceae) }\end{array}$ & Exerts AChE inhibitory activity in vitro & {$[26]$} \\
\hline 4. & $\begin{array}{l}\text { Bacopa monnieri (L.) Pennel } \\
\text { (Plantaginaceae) }\end{array}$ & $\begin{array}{c}\text { Improved cognitive function and reduced loss of neurons in animal model of AD. } \\
\text { Enhances learning and memory in randomized double blind placebo controlled } \\
\text { trial. }\end{array}$ & {$[27-32]$} \\
\hline 5. & $\begin{array}{l}\text { Berberis darwinii Hook } \\
\text { (Berberidaceae) }\end{array}$ & Exerts $\mathrm{AChE}$ inhibitory activity in vitro. & {$[33]$} \\
\hline 6. & $\begin{array}{l}\text { Cassia obtusifolia (L.), Syn.: Senna } \\
\text { obtusifolia (L.) H.S. Irwin \& Barneby } \\
\text { (Fabaceae) }\end{array}$ & $\begin{array}{l}\text { Attenuates oxidative stress and } \mathrm{Ca}^{+2} \text { dysregulation in primary hippocampal } \\
\text { cultures. }\end{array}$ & {$[34]$} \\
\hline 7. & $\begin{array}{l}\text { Caulis spatholobi (L.) } \\
\text { (Fabaceae) }\end{array}$ & Exerts AChE inhibitory activity & $\begin{array}{l}{[35-40,41,42-} \\
45]\end{array}$ \\
\hline 8. & $\begin{array}{l}\text { Celastrus paniculatus Willd. } \\
\text { (Celastraceae) }\end{array}$ & It sharpens memory and improves concentration as well as cognitive function. & {$[32]$} \\
\hline 9. & $\begin{array}{l}\text { Centella asiatica }(\mathrm{L} .), \mathrm{Urb} . \\
\text { (Apiaceae) }\end{array}$ & $\begin{array}{l}\text { Reduces apoptosis and hippocampal } \mathrm{A} \beta \text { levels in vitro and in vivo. Enhances } \\
\text { learning and memory function in mice models of } \mathrm{AD} \text {. Potential use in the } \\
\text { prevention and treatment of beta-amyloid toxicity and } \mathrm{AD} \text {. }\end{array}$ & {$[32,46-48]$} \\
\hline 10. & $\begin{array}{c}\text { Cinnamomum zeylanicum, Blume } \\
\text { (Lauraceae) }\end{array}$ & $\begin{array}{c}\text { Inhibits the formation of } \mathrm{A} \beta \text { oligomers. } \\
\text { Reduces } \mathrm{A} \beta \text { toxicity in neuronal PC12 cells. } \\
\text { Reduces } \mathrm{A} \beta \text { oligomer and improves cognition in mice model of } \mathrm{AD} \text {. }\end{array}$ & {$[49]$} \\
\hline 11. & Citrus medica (L.) (Rutaceae) & Elicits anti-cholinesterase activity. & {$[50]$} \\
\hline 12. & $\begin{array}{l}\text { Cocus nucifera }(\mathrm{L} .) \\
\quad \text { (Arecaceae) }\end{array}$ & $\begin{array}{l}\text { Reduces deposition of } \mathrm{A} \beta \text { in cerebral cortex and tau-1 expression in } \\
\text { hippocampus. } \\
\text { Protect from amyloidosis and taupathy (neurofibrillary targets in brain of } \\
\text { ovarictomized rats. } \\
\text { Estrogenic activity. }\end{array}$ & {$[51,52,53,54]$} \\
\hline 13. & $\begin{array}{l}\text { Collinsonia candadensis (L.) } \\
\text { (Lamiaceae) }\end{array}$ & $\begin{array}{l}\text { Called horsebalm. Major constituents are carvacol and thymol that crosses blood- } \\
\text { brain barrier which are used for AD, }\end{array}$ & {$[55]$} \\
\hline 14. & $\begin{array}{l}\text { Convolvulus pluricaulis Choisy } \\
\text { (Convolvulaceae) }\end{array}$ & Dose-dependent enhancement of memory was found in mice. & {$[32]$} \\
\hline 15. & $\begin{array}{l}\text { Curcuma longa }(\mathrm{L} .) \\
\text { (Zingiberaceae) }\end{array}$ & $\begin{array}{c}\text { Statistics indicate definitely (4.4-fold) lower incidence of AD in countries where } \\
\text { Curcuma longa is part of daily diet. }\end{array}$ & {$[32]$} \\
\hline 16. & Danggui-Shaoyao-San (Apiaceae) & $\begin{array}{c}\text { Improve cognitive function in age related memory dusfunction, reduces A } \beta 25-35 \\
\text { induced neuronal cell death and antiapoptotic effect in PC12 cells, ameliorate } \\
\text { A } \beta 25-35 \text { induced impairment of spatial learning and memory in mice }\end{array}$ & {$[56,57,58,59]$} \\
\hline
\end{tabular}


(Table 1) contd.....

\begin{tabular}{|c|c|c|c|}
\hline No. & Medicinal Plants, Name and (Family) & Mechanism of Action & References \\
\hline 17. & $\begin{array}{l}\text { Desmodium gangeticum (L.) } \\
\text { (Fabaceae) }\end{array}$ & $\begin{array}{c}\text { Elicits AChE inhibitory activity. Improves learning and memory in scopolamine } \\
\text { and ageing models of AD in mice }\end{array}$ & {$[60]$} \\
\hline 18. & $\begin{array}{l}\text { Epimedium koreanum (L.) } \\
\text { (Berberidaceae) }\end{array}$ & Exerts AChE inhibitory activity in vitro & {$[61]$} \\
\hline 19. & $\begin{array}{l}\text { Ganoderma lucidum } \\
\text { Curtis) P. Karst } \\
\text { (Ganodermataceae) }\end{array}$ & $\begin{array}{l}\text { Attenuates } A \beta \text { induced synaptotoxicity by preserving synaptophysin and inhibits } \\
A \beta \text { induced apoptosis and c-JNK phosphorylation }\end{array}$ & {$[62,63]$} \\
\hline 20. & $\begin{array}{c}\text { Erigon breviscapus } \\
\text { (Vaniot) Hand.-Mazz. (Asteraceae) }\end{array}$ & $\begin{array}{l}\text { Suppresses lipid peroxidation, expression of nACh } \alpha-7 \text { protein, } \beta \text { Apeptide in } \\
\text { SH-SY5Y cells }\end{array}$ & {$[64,65]$} \\
\hline 21. & $\begin{array}{c}\text { Hupezia serrata } \\
\text { (Thunb. ex Murray) Trevis (Huperziaceae) }\end{array}$ & $\begin{array}{l}\text { National Institute of Aging has the clinical trial in Phase II of its extract } \\
\text { particularly on AD. }\end{array}$ & \\
\hline 22. & $\begin{array}{l}\text { Lavendula angustifolia } \\
\quad \text { Mill. (Lamiaceae) }\end{array}$ & $\begin{array}{l}\text { Reduces aggression and improves neuropsychiatric behavior in a cross over } \\
\text { randomized trial for treating agitated behaviors of demented people in Hong } \\
\text { Kong. }\end{array}$ & {$[66,67,68,69]$} \\
\hline 23. & $\begin{array}{l}\text { Lycium barbarum }(\mathrm{L} .) \\
\quad \text { (Solanacea) }\end{array}$ & $\begin{array}{l}\text { Protects against the toxicity of fibrillar } \mathrm{A} \beta_{1-42} \text { and } \mathrm{A} \beta_{25-35} \text { in rat cortical neurons } \\
\text { Exerts antioxidant and antiapoptotic activity }\end{array}$ & {$[70,71,72]$} \\
\hline 24. & $\begin{array}{l}\text { Malus domestica } \\
\text { Borkh. (Rosaceae) }\end{array}$ & $\begin{array}{l}\text { Improves learning and memory in and process organized synaptic signaling in } \\
\text { open label trial } \\
\text { Exerts antioxidant activity in mice model of AD }\end{array}$ & {$[73,74]$} \\
\hline 25. & $\begin{array}{c}\text { Morus alba L. syn.: Morus atropurpurea } \\
\text { Roxb. (Moraceae) }\end{array}$ & $\begin{array}{l}\text { Augments the antioxidant defense system } \\
\text { Improves learning and memory in mice model of AD }\end{array}$ & {$[75]$} \\
\hline 26. & $\begin{array}{l}\text { Murraya koenigii } \\
\text { Sprangel } \\
\text { (Rutaceae) }\end{array}$ & Improves memory and learning in mice models of $\mathrm{AD}$ & {$[76]$} \\
\hline 27. & $\begin{array}{l}\text { Oldenlandia affinis } \\
\text { Roem. \& Schult. } \\
\text { (Rubiaceae) }\end{array}$ & Inhibits $\beta$-secretase activity and decreases $A \beta$ production & [78] \\
\hline 28. & $\begin{array}{l}\text { Paeonia suffruticosa } \\
\text { Andrews } \\
\text { (Paeoniceae) }\end{array}$ & Inhibits $\beta$-secretase activity and decreases $A \beta$ production & {$[79,80]$} \\
\hline 29. & $\begin{array}{l}\text { Phangnalon saxatile (L.) Cass. } \\
\text { (Asteraceae) }\end{array}$ & Exhibits antioxidant and acetyl cholinesterase inhibitory activity. & {$[81,82]$} \\
\hline 30. & $\begin{array}{c}\text { Physostigma venenosa (L.) Balf. } \\
\text { (Labiatae) }\end{array}$ & $\begin{array}{l}\text { Its physostigmine content has relevance to cholinergic therapy in Alzheimer's } \\
\text { disease }\end{array}$ & [83] \\
\hline 31. & $\begin{array}{l}\text { Pinus nigra J.F. Arnold, Syn.: Pinus } \\
\text { heldreichii } \mathrm{H} . \text { Christ } \\
\text { (Pinaceae) }\end{array}$ & Exerts AChE inhibitory activity in vitro & [84] \\
\hline 32. & $\begin{array}{l}\text { Prosopis Africana } \\
\text { (Guill. \& Perr) Taub. } \\
\quad \text { (Fabaceae) }\end{array}$ & Inhibits $\beta$-secretase activity and decreases $A \beta$ production & [78] \\
\hline 33. & $\begin{array}{l}\text { Pterocarpus erinaceus } \\
\text { Poir. (Fabaceae) }\end{array}$ & Inhibits $\beta$-secretase activity and decreases $A \beta$ production & {$[85,86]$} \\
\hline 34. & $\begin{array}{l}\text { Punica granatum }(\mathrm{L} .) \\
\quad \text { (Lythraceae) }\end{array}$ & $\begin{array}{l}\text { Reduces accumulation of } \mathrm{A} \beta 42 \text { and amyloid deposition in hippocampus in } \\
\text { transgenic mice (APP (SW)/Tg2576) and protected PC12 cells from } \mathrm{H}_{2} \mathrm{O}_{2} \\
\text { induced oxidative stress and increases cognitive function, and inhibits cell death } \\
\text { by } \mathrm{A} \beta \text { induced oxidative stress in mice. }\end{array}$ & {$[87-91]$} \\
\hline 35. & $\begin{array}{c}\text { Paeoniae alba } \\
\text { Pall. (Paeoniaceae) }\end{array}$ & Exerts AChE inhibitory activity & $\begin{array}{l}{[35-40,41,42-} \\
45]\end{array}$ \\
\hline 36. & $\begin{array}{l}\text { Salvia miltiorrhizae } \\
\text { Bunge (Labiatae) }\end{array}$ & Exerts AChE inhibitory activity & $\begin{array}{c}{[35-40,41,42-} \\
45]\end{array}$ \\
\hline 37. & $\begin{array}{l}\text { Rehmannia glutinosa (Gaertn) Steud, } \\
\text { (Orbanchanceae) }\end{array}$ & $\begin{array}{l}\text { Induces the expression of glial cell line derived neurotropic factor (GDNF) in } \\
\text { cells and cultured astrocytes }\end{array}$ & $\begin{array}{c}{[92,93,94,95]} \\
{[96,97,98]}\end{array}$ \\
\hline 38. & $\begin{array}{c}\text { Rhizophora x lamarckii } \\
\text { (Hybrid of Rhizophora apiculata \& } R \text {. } \\
\text { Stylosa } \\
\text { (Rhizophoraceae) }\end{array}$ & Exerts AChE inhibitory activity in vitro & [26] \\
\hline 39. & $\begin{array}{c}\text { Salvia leriifolia } \\
\text { Benth. (Lamiaceae) }\end{array}$ & Exerts antioxidant, anti-inflammatory and cholinesterase inhibitory activity. & {$[99,100]$} \\
\hline 40. & $\begin{array}{l}\text { Salvia officinalis, }(L) \\
\quad \text { (Lamiaceae) }\end{array}$ & $\begin{array}{l}\text { Protects PC12 cells from neurotoxicity and tau protein hyperphosphorylation. } \\
\text { Improves learning and memory in patients of moderate AD in a double blind } \\
\text { randmozed placebo controlled multicenter trial. }\end{array}$ & $\begin{array}{l}{[101,102,103,} \\
104,105]\end{array}$ \\
\hline
\end{tabular}


(Table 1) contd.....

\begin{tabular}{|c|c|c|c|}
\hline No. & Medicinal Plants, Name and (Family) & Mechanism of Action & References \\
\hline 41. & $\begin{array}{l}\text { Salvia sclareoides Brot. } \\
\text { (Lamiaceae) }\end{array}$ & Exerts AChE inhibitory activity in vitro & {$[106,107,108]$} \\
\hline 42. & $\begin{array}{l}\text { Sesuvium portulacastrum }(L) \\
\text { (Aizoaceae) }\end{array}$ & Exerts AChE inhibitory activity in vitro & {$[26]$} \\
\hline 43. & $\begin{array}{l}\text { Suaeda monica Forsk. Ex J.F. Gmel. } \\
\text { (Chenopodiaceae) }\end{array}$ & Exerts AChE inhibitory activity in vitro & {$[26]$} \\
\hline 44. & $\begin{array}{l}\text { Tabernaemontana divaricata(L) R.Br. ex } \\
\text { Roem. \& Schult. } \\
\text { (Apocynaeeae) }\end{array}$ & Inhibits cortical AChE activity and enhances cortical neuronal activity & [109] \\
\hline 45. & Thespesia populnea (L) (Malvaceae) & $\begin{array}{l}\text { Exerts inhibition of AChE activity. Improves learning and memory in diazepam } \\
\text { and scopolamine models of AD in mice. }\end{array}$ & {$[110]$} \\
\hline 46. & $\begin{array}{l}\text { Trichilia emetic Vahl. } \\
\text { (Meliaceae) }\end{array}$ & Inhibits $\beta$-secretase activity and decreases $A \beta$ production & {$[85,86]$} \\
\hline 47. & $\begin{array}{l}\text { Uncaria rhynchophylla } \\
\text { (Miq.) (Rubiaceae) }\end{array}$ & Inhibits fibril formation of both $\mathrm{A} \beta_{1-40}$ and $\mathrm{A} \beta_{1-42}$ in vitro & $\begin{array}{l}{[111],[112,113,} \\
114,115]\end{array}$ \\
\hline 48. & $\begin{array}{l}\text { Valeriana amurensis P. Smirn. } \\
\text { (Valerianaceae) }\end{array}$ & $\begin{array}{l}\text { Inhibits the expression of } \beta \text {-APP, } \mathrm{A} \beta_{1-40} \text { and formation of senile plaques } \\
\text { decreases. } \\
\text { Reduces pro-inflammatory cytokines and cellular fate of cortical and } \\
\text { hippocampal neurons in rat model of } \mathrm{AD} \text {. }\end{array}$ & $\begin{array}{l}{[116,117,118,} \\
119]\end{array}$ \\
\hline 49. & $\begin{array}{l}\text { Vitis amurensis Rupr. } \\
\text { (Vitaceae) }\end{array}$ & $\begin{array}{l}\text { Inhibits neuronal apoptosis and exhibit antioxidant activity in cultures of rat } \\
\text { cortical neurons. Improves learning and memory in mice models of AD }\end{array}$ & {$[120]$} \\
\hline 50. & $\begin{array}{l}\text { Withania somnifera }(\mathrm{L}) \text { Dunal } \\
\text { (Solanaceae) }\end{array}$ & $\begin{array}{c}\text { Semipurified extract of Withania somnifera reverses Alzheimer's disease } \\
\text { pathology. Nerving tonic, aphrodistic, rejuvenative, antioxidant activity, calming } \\
\text { effect, reverses behavioural deficit. }\end{array}$ & {$[32,121-126]$} \\
\hline 51. & $\begin{array}{c}\text { Zingiber officinalis } \text { Rosc. } \\
\text { (Zingeberaceae) }\end{array}$ & Exerts $\mathrm{A} \beta$ aggregating, antioxidant and $\mathrm{AChE}$ inhibitory activity. & {$[127,128]$} \\
\hline
\end{tabular}

Pharmacological investigations of plant-based anti- Alzheimer's agents have led to the successful introduction of galantamine into the clinical use; clinical trials with or huperzine A are going on.

The degeneration of acetylcholine ( $\mathrm{ACh}$ ) neurotransmission in the central nervous system due to neural degradation is considered to be a major neuropathological characteristic of $\mathrm{AD}$ [14]. The animal models of AD are based on the use of scopolamine (SCOP) to block muscarinic ACh receptors, which results in cognitive impairment $[15,16]$. The SCOP model is widely used to assess the activity of antidementia agents. At the same time, other neurotoxins, e.g. an inhibitor of RNA-protein translation (cycloheximide), a serotonin neurotoxin (para-chloro-amphetamine), the amyloid $\beta$-peptide, the ethanol, the aluminum applied on animal models of AD have also proved used to impair cognitive functions. The cognitive or antidementia effects of herbal agents on behavioral pharmacological models, as soon as the passive avoidance test, the Morris water maze test, the T-maze, and both the radial maze paradigms were also checked. Although the mechanisms responsible for the cognition-enhancing effects of most herbal extracts and phytoconstituents are still not completely understood. One or more of the following factors are involved in the improvement of central ACh function; Inhibition of acetylcholinesterase (AChE) and facilitation of ACh synthesis or facilitation of the ACh receptor function; prevention of $\beta$-amyloidogenesis by antioxidant action; protection against neurotoxicity and death of nerve cells; facilitation of some neurotrophic effects, e.g., nerve growth factor (NGF). In the field of drug discovery, more attention has been focused on neuroprotection in AD utilizing traditional medicinal plants. Natural compounds with anti- oxidant, anti-inflammatory, anti-apoptotic, and neurofunctional regulational effects may exhibit preventive or therapeutic features against AD. Herbal drugs of traditional medicine which have been well characterized and studied for their behavioral effects and pharmacological properties, may be attractive candidates for further approved for the treatment of patients with Alzheimer's disease, many herbal agents appeared to inhibit of AChE activity.

Tacrine was discriminated in 2013 because of concerns of hepatotoxicity. At the same time, substantial number of herbal extracts and isolated constituents have antioxidant and neuroprotective effects. Antidementia effects are evidenced from in vitro results when protection from nerve cell death was induced by exposure to abundant free radicals, excitatory toxins, toxic derivatives of amyloid precursor protein, and other neurotoxins.

\section{CONCLUSION}

Here we reiterate the fact that natural products represent sources of compounds having potential therapeutic implication in $\mathrm{AD}$ and other cognitive dysfunctions.

Discovery of drugs from medicinal plants has traditionally been a long process and more cumbersome than other 
ways of development.

Bioassay screening of extract libraries faces significant difficulties and finding of lead compound libraries is a crucial strategy for discovering drugs. Revealing the precise pathogenesis of AD will give a wider insight into new drug discovery and development and will rationalize drug design with better outcomes and therapeutic benefits. Considering the multitarget, multicomponent action strategy of natural products widely used in the traditional medicine in AD, they offer an unexploited source of new and effective therapy. The traditionally applied herbal preparations offer an adjunctive therapy to drugs acting on amyloidogenesis, AChE and cell death are intensively tested in order to offer better therapeutic prospects in the improvement of learning and memory functions of patients suffering from AD. Currently, very few plant-based medicines are accepted for clinical application. The reasons behind these very few approvals seem to be the complex nature of the chemical components in herbal preparations, difficulties in standardization. Identification of the active ingradient(s) of medical herbs would significantly increase acceptance of these medicinal plants in the clinical practice. The information provided in the present review on numerous plant extracts, formulations and phytoconstituents that have preventive and therapeutic effects on AD in animal models can be used to find new drug therapies for $\mathrm{AD}$ and related sequels.

In view of detrimental actions of the agents for $\mathrm{AD}$, in particular treatment refractoriness, high recurrence and side effects that occur in the course of long-term treatments, herbal drugs may offer an alternative possibility. In fact, some human studies have confirmed the beneficial effects of herbal medicines in the prevention and treatment of dementia [17 - 21]. Based on the encouraging results from animal studies and time-tested safety of some of the herbal agents, the use of these agents as an adjunctive therapy along with conventional drugs can be suggested.

The therapeutic effects of most herbal agents reviewed in this paper are still to be confirmed in clinical settings [22].

\section{CONSENT FOR PUBLICATION}

Not applicable.

\section{CONFLICT OF INTEREST}

The authors declare no conflict of interest, financial or otherwise.

\section{ACKNOWLEDGEMENTS}

Declared none.

\section{REFERENCES}

[1] Brunton, L.L.; Lazo, J.S.; Parker, K.L. Goodman \& Gilman's The Pharmacological Basis of Therapeutics, The, 11th ed; McGraw-Hill: New York, 2006, p. 538.

[2] Bergamaschi, S.; Binetti, G.; Govoni, S.; Wetsel, W.C.; Battaini, F.; Trabucchi, M.; Bianchetti, A.; Racchi, M. Defective phorbol esterstimulated secretion of beta-amyloid precursor protein from Alzheimer's disease fibroblasts. Neurosci. Lett., 1995, $201(1), 1-5$. [http://dx.doi.org/10.1016/0304-3940(95)12168-4] [PMID: 8830300]

[3] Zhou, Y.; Liu, L.; Hao, Y.; Xu, M. Detection of A $\beta$ Monomers and Oligomers: Early Diagnosis of Alzheimer's Disease. Chem. Asian J., 2016, 11(6), 805-817.

[http://dx.doi.org/10.1002/asia.201501355] [PMID: 26994700]

[4] Beck, J.C.; Benson, D.F.; Scheibel, A.B.; Spar, J.E.; Rubenstein, L.Z. Dementia in the elderly: The silent epidemic. Ann. Intern. Med., 1982, 97(2), 231-241.

[http://dx.doi.org/10.7326/0003-4819-97-2-231] [PMID: 7049032]

[5] Razay, G.; Wilcock, G.K. Hyperinsulinaemia and Alzheimer's disease. Age Ageing, 1994, 23(5), 396-399. [http://dx.doi.org/10.1093/ageing/23.5.396] [PMID: 7825486]

[6] Báthori, M.; Tóth, N.; Hunyadi, A.; Márki, A.; Zádor, E. Phytoecdysteroids and anabolic-androgenic steroids-structure and effects on humans. Curr. Med. Chem., 2008, 15(1), 75-91. [http://dx.doi.org/10.2174/092986708783330674] [PMID: 18220764]

[7] Tappayuthpijarn, P.; Itharat, A.; Makchuchit, S. Acetylcholinesterase inhibitory activity of Thai traditional nootropic remedy and its herbal ingredients. J. Med. Assoc. Thai., 2011, 94(Suppl. 7), S183-S189. [PMID: 22619927]

[8] da Rocha, M.D.; Viegas, F.P.; Campos, H.C.; Nicastro, P.C.; Fossaluzza, P.C.; Fraga, C.A.; Barreiro, E.J.; Viegas, C., Jr The role of natural products in the discovery of new drug candidates for the treatment of neurodegenerative disorders II: Alzheimer's disease. CNS Neurol. Disord. Drug Targets, 2011, 10(2), 251-270.

[http://dx.doi.org/10.2174/187152711794480429] [PMID: 20874701] 
[9] Eckert, A.; Schulz, K.L.; Rhein, V.; Götz, J. Convergence of amyloid-beta and tau pathologies on mitochondria in vivo. Mol. Neurobiol., 2010, 41(2-3), 107-114.

[http://dx.doi.org/10.1007/s12035-010-8109-5] [PMID: 20217279]

[10] Eckert, G.P. Traditional used plants against cognitive decline and Alzheimer disease. Front. Pharmacol., 2010, 1, 138. [http://dx.doi.org/10.3389/fphar.2010.00138] [PMID: 21833177]

[11] Mukherjee, P.K.; Kumar, V.; Mal, M.; Houghton, P.J. Acetylcholinesterase inhibitors from plants. Phytomedicine, 2007, 14(4), 289-300. [http://dx.doi.org/10.1016/j.phymed.2007.02.002] [PMID: 17346955]

[12] Kim, J.; Lee, H.J.; Lee, K.W. Naturally occurring phytochemicals for the prevention of Alzheimer's disease. J. Neurochem., 2010, 112(6), 1415-1430. [http://dx.doi.org/10.1111/j.1471-4159.2009.06562.x] [PMID: 20050972]

[13] Man, S.C.; Durairajan, S.S.; Kum, W.F.; Lu, J.H.; Huang, J.D.; Cheng, C.F.; Chung, V.; Xu, M.; Li, M. Systematic review on the efficacy and safety of herbal medicines for Alzheimer's disease. J. Alzheimers Dis., 2008, 14(2), 209-223. [http://dx.doi.org/10.3233/JAD-2008-14209] [PMID: 18560132]

[14] Howes, M.J.; Perry, N.S.; Houghton, P.J. Plants with traditional uses and activities, relevant to the management of Alzheimer's disease and other cognitive disorders. Phytother. Res., 2003, 17(1), 1-18. [http://dx.doi.org/10.1002/ptr.1280] [PMID: 12557240]

[15] Sunderland, T.; Tariot, P.; Murphy, D.L.; Weingartner, H.; Mueller, E.A.; Cohen, R.M. Scopolamine challenges in Alzheimer's disease. Psychopharmacology (Berl.), 1985, 87(2), 247-249. [http://dx.doi.org/10.1007/BF00431817] [PMID: 3931154]

[16] Perry, G.; Taddeo, M.A.; Nunomura, A.; Zhu, X.; Zenteno-Savin, T.; Drew, K.L.; Shimohama, S.; Avila, J.; Castellani, R.J.; Smith, M.A. Comparative biology and pathology of oxidative stress in Alzheimer and other neurodegenerative diseases: Beyond damage and response. Comp. Biochem. Physiol. C Toxicol. Pharmacol., 2002, 133(4), 507-513. [http://dx.doi.org/10.1016/S1532-0456(02)00119-9] [PMID: 12458179]

[17] Wong, A.H.; Smith, M.; Boon, H.S. Herbal remedies in psychiatric practice. Arch. Gen. Psychiatry, 1998, 55(11), $1033-1044$. [http://dx.doi.org/10.1001/archpsyc.55.11.1033] [PMID: 9819073]

[18] Fugh-Berman, A.; Cott, J.M. Dietary supplements and natural products as psychotherapeutic agents. Psychosom. Med., 1999, 61(5), 712-728. [http://dx.doi.org/10.1097/00006842-199909000-00012] [PMID: 10511018]

[19] Perry, E.; Howes, M.J. Medicinal plants and dementia therapy: Herbal hopes for brain aging? CNS Neurosci. Ther., 2011, 17(6), 683-698. [http://dx.doi.org/10.1111/j.1755-5949.2010.00202.x] [PMID: 22070157]

[20] Perry, G.; Nunomura, A.; Raina, A.K.; Aliev, G.; Siedlak, S.L.; Harris, P.L.; Casadesus, G.; Petersen, R.B.; Bligh-Glover, W.; Balraj, E.; Petot, G.J.; Smith, M.A. A metabolic basis for Alzheimer disease. Neurochem. Res., 2003, 28(10), 1549-1552. [http://dx.doi.org/10.1023/A:1025678510480] [PMID: 14570400]

[21] Wong, P.C.; Borchelt, D.R.; Lee, M.K.; Pardo, C.A.; Thinakaran, G.; Martin, L.J.; Sisodia, S.S.; Price, D.L. Familial amyotrophic lateral sclerosis and Alzheimer's disease. Transgenic models. Adv. Exp. Med. Biol., 1998, 446, 145-159. [http://dx.doi.org/10.1007/978-1-4615-4869-0_9] [PMID: 10079842]

[22] Grossberg, G.T.; Desai, A.K. Management of Alzheimer's disease. J. Gerontol. A Biol. Sci. Med. Sci., 2003, 58(4), $331-353$. [http://dx.doi.org/10.1093/gerona/58.4.M331] [PMID: 12663697]

[23] Kim, K.; Bu, Y.; Jeong, S.; Lim, J.; Kwon, Y.; Cha, D.S.; Kim, J.; Jeon, S.; Eun, J.; Jeon, H. Memory-enhancing effect of a supercritical carbon dioxide fluid extract of the needles of Abies koreana on scopolamine-induced amnesia in mice. Biosci. Biotechnol. Biochem., 2006, $70(8), 1821-1826$. [http://dx.doi.org/10.1271/bbb.50608] [PMID: 16926492]

[24] Liu, Z.B.; Niu, W.M.; Yang, X.H.; Wang, Y.; Wang, W.G. Study on perfume stimulating olfaction with volatile oil of Acorus gramineus for treatment of the Alzheimer's disease rat. J. Tradit. Chin. Med., 2010, 30(4), 283-287. [http://dx.doi.org/10.1016/S0254-6272(10)60057-X] [PMID: 21287786]

[25] Geng, Y.; Li, C.; Liu, J.; Xing, G.; Zhou, L.; Dong, M.; Li, X.; Niu, Y. Beta-asarone improves cognitive function by suppressing neuronal apoptosis in the beta-amyloid hippocampus injection rats. Biol. Pharm. Bull., 2010, 33(5), 836-843. [http://dx.doi.org/10.1248/bpb.33.836] [PMID: 20460763]

[26] Suganthy, N.; Pandian, S.K.; Devi, K.P. Cholinesterase inhibitory effects of Rhizophora lamarckii, Avicennia officinalis, Sesuvium portulacastrum and Suaeda monica: Mangroves inhabiting an Indian coastal area (Vellar Estuary). J. Enzyme Inhib. Med. Chem., 2009, 24(3), $702-707$.

[http://dx.doi.org/10.1080/14756360802334719] [PMID: 18686140]

[27] Uabundit, N.; Wattanathorn, J.; Mucimapura, S.; Ingkaninan, K. Cognitive enhancement and neuroprotective effects of Bacopa monnieri in Alzheimer's disease model. J. Ethnopharmacol., 2010, 127(1), 26-31. [http://dx.doi.org/10.1016/j.jep.2009.09.056] [PMID: 19808086]

[28] Howes, M.J.; Houghton, P.J. Ethnobotanical treatment strategies against Alzheimer's disease. Curr. Alzheimer Res., 2012, 9(1), 67-85. [http://dx.doi.org/10.2174/156720512799015046] [PMID: 22329652] 
[29] Saini, N.; Singh, D.; Sandhir, R. Neuroprotective effects of Bacopa monnieri in experimental model of dementia. Neurochem. Res., 2012, 37(9), 1928-1937. [http://dx.doi.org/10.1007/s11064-012-0811-4] [PMID: 22700087]

[30] Zhang, L.N.; Sun, Y.J.; Pan, S.; Li, J.X.; Qu, Y.E.; Li, Y.; Wang, Y.L.; Gao, Z.B. Na-K-ATPase, a potent neuroprotective modulator against Alzheimer disease. Fundam. Clin. Pharmacol., 2013, 27(1), 96-103. [http://dx.doi.org/10.1111/fcp.12000] [PMID: 23033963]

[31] Rasool, M.; Malik, A.; Qazi, A.M.; Sheikh, I.A.; Manan, A.; Shaheen, S.; Qazi, M.H.; Chaudhary, A.G.; Abuzenadah, A.M.; Asif, M.; Alqahtani, M.H.; Iqbal, Z.; Shaik, M.M.; Gan, S.H.; Kamal, M.A. Current view from Alzheimer disease to type 2 diabetes mellitus. CNS Neurol. Disord. Drug Targets, 2014, 13(3), 533-542. [http://dx.doi.org/10.2174/18715273113126660167] [PMID: 24059295]

[32] Rao, R.V.; Descamps, O.; John, V.; Bredesen, D.E. Ayurvedic medicinal plants for Alzheimer's disease: A review. Alzheimers Res. Ther., 2012, 4(3), 22-31

[http://dx.doi.org/10.1186/alzrt125] [PMID: 22747839]

[33] Habtemariam, S. The therapeutic potential of Berberis darwinii stem-bark: quantification of berberine and in vitro evidence for Alzheimer's disease therapy. Nat. Prod. Commun., 2011, 6(8), 1089-1090. [PMID: 21922905]

[34] Drever, B.D.; Anderson, W.G.; Riedel, G.; Kim, D.H.; Ryu, J.H.; Choi, D.Y.; Platt, B. The seed extract of Cassia obtusifolia offers neuroprotection to mouse hippocampal cultures. J. Pharmacol. Sci., 2008, 107(4), 380-392. [http://dx.doi.org/10.1254/jphs.08034FP] [PMID: 18719316]

[35] Jiang, P.; Li, C.; Xiang, Z.; Jiao, B. Tanshinone IIA reduces the risk of Alzheimer's disease by inhibiting iNOS, MMP2 and NFкBp65 transcription and translation in the temporal lobes of rat models of Alzheimer's disease. Mol. Med. Rep., 2014, 10(2), 689-694. [http://dx.doi.org/10.3892/mmr.2014.2254] [PMID: 24859152]

[36] Buenafe, O.E.; Orellana-Paucar, A.; Maes, J.; Huang, H.; Ying, X.; De Borggraeve, W.; Crawford, A.D.; Luyten, W.; Esguerra, C.V.; de Witte, P. Tanshinone IIA exhibits anticonvulsant activity in zebrafish and mouse seizure models. ACS Chem. Neurosci., 2013, 4(11), 1479-1487.

[http://dx.doi.org/10.1021/cn400140e] [PMID: 23937066]

[37] Cao, Y.Y.; Wang, L.; Ge, H.; Lu, X.L.; Pei, Z.; Gu, Q.; Xu, J. Salvianolic acid A, a polyphenolic derivative from Salvia miltiorrhiza bunge, as a multifunctional agent for the treatment of Alzheimer's disease. Mol. Divers., 2013, 17(3), 515-524. [http://dx.doi.org/10.1007/s11030-013-9452-z] [PMID: 23703159]

[38] Hu, H.; Zhou, D.S.; Yu, R. Effects of compound danshen tablet on the expression of Abeta in transgenic cell model of Alzheimer's disease. Zhongguo Zhong Xi Yi Jie He Za Zhi, 2012, 32(12), 1663-1666. [PMID: 23469608]

[39] Lee, Y.W.; Kim, D.H.; Jeon, S.J.; Park, S.J.; Kim, J.M.; Jung, J.M.; Lee, H.E.; Bae, S.G.; Oh, H.K.; Son, K.H.; Ryu, J.H. Neuroprotective effects of salvianolic acid B on an A $\beta 25-35$ peptide-induced mouse model of Alzheimer's disease. Eur. J. Pharmacol., 2013, 704(1-3), 70-77. [http://dx.doi.org/10.1016/j.ejphar.2013.02.015] [PMID: 23461850]

[40] Han, M.; Liu, Y.; Zhang, B.; Qiao, J.; Lu, W.; Zhu, Y.; Wang, Y.; Zhao, C. Salvianic borneol ester reduces $\beta$-amyloid oligomers and prevents cytotoxicity. Pharm. Biol., 2011, $49(10), 1008-1013$ [http://dx.doi.org/10.3109/13880209.2011.559585] [PMID: 21936627]

[41] Jeon, S.; Bose, S.; Hur, J.; Jun, K.; Kim, Y.K.; Cho, K.S.; Koo, B.S. A modified formulation of Chinese traditional medicine improves memory impairment and reduces A $\beta$ level in the Tg-APPswe/PS1dE9 mouse model of Alzheimer's disease. J. Ethnopharmacol., 2011, 137(1), 783-789. [http://dx.doi.org/10.1016/j.jep.2011.06.046] [PMID: 21762767]

[42] Wong, K.K.; Ho, M.T.; Lin, H.Q.; Lau, K.F.; Rudd, J.A.; Chung, R.C.; Fung, K.P.; Shaw, P.C.; Wan, D.C. Cryptotanshinone, an acetylcholinesterase inhibitor from Salvia miltiorrhiza, ameliorates scopolamine-induced amnesia in Morris water maze task. Planta Med., 2010, 76(3), 228-234.

[http://dx.doi.org/10.1055/s-0029-1186084] [PMID: 19774505]

[43] Mei, Z.; Zhang, F.; Tao, L.; Zheng, W.; Cao, Y.; Wang, Z.; Tang, S.; Le, K.; Chen, S.; Pi, R.; Liu, P. Cryptotanshinone, a compound from Salvia miltiorrhiza modulates amyloid precursor protein metabolism and attenuates beta-amyloid deposition through upregulating alphasecretase in vivo and in vitro. Neurosci. Lett., 2009, 452(2), 90-95.

[http://dx.doi.org/10.1016/j.neulet.2009.01.013] [PMID: 19154776]

[44] Yu, X.Y.; Lin, S.G.; Chen, X.; Zhou, Z.W.; Liang, J.; Duan, W.; Chowbay, B.; Wen, J.Y.; Chan, E.; Cao, J.; Li, C.G.; Zhou, S.F. Transport of cryptotanshinone, a major active triterpenoid in Salvia miltiorrhiza Bunge widely used in the treatment of stroke and Alzheimer's disease, across the blood-brain barrier. Curr. Drug Metab., 2007, 8(4), 365-378. [http://dx.doi.org/10.2174/138920007780655441] [PMID: 17504224]

[45] Ren, Y.; Houghton, P.J.; Hider, R.C.; Howes, M.J. Novel diterpenoid acetylcholinesterase inhibitors from Salvia miltiorhiza. Planta Med., 2004, 70(3), 201-204. [http://dx.doi.org/10.1055/s-2004-815535] [PMID: 15114495]

[46] Dhanasekaran, M.; Holcomb, L.A.; Hitt, A.R.; Tharakan, B.; Porter, J.W.; Young, K.A.; Manyam, B.V. Centella asiatica extract selectively 
decreases amyloid beta levels in hippocampus of Alzheimer's disease animal model. Phytother. Res., 2009, 23(1), 14-19. [http://dx.doi.org/10.1002/ptr.2405] [PMID: 19048607]

[47] Xu, Y.; Cao, Z.; Khan, I.; Luo, Y. Gotu Kola (Centella Asiatica) extract enhances phosphorylation of cyclic AMP response element binding protein in neuroblastoma cells expressing amyloid beta peptide. J. Alzheimers Dis., 2008, 13(3), 341-349. [http://dx.doi.org/10.3233/JAD-2008-13311] [PMID: 18431001]

[48] Dhanasekaran, M.; Holcomb, L.A.; Hitt, A.R.; Tharakan, B.; Porter, J.W.; Young, K.A.; Manyam, B.V. Centella asiatica extract selectively decreases amyloid beta levels in hippocampus of Alzheimer's disease animal model. Phytother. Res., 2009, 23(1), 14-19. [http://dx.doi.org/10.1002/ptr.2405] [PMID: 19048607]

[49] Frydman-Marom, A.; Levin, A.; Farfara, D.; Benromano, T.; Scherzer-Attali, R.; Peled, S.; Vassar, R.; Segal, D.; Gazit, E.; Frenkel, D.; Ovadia, M. Orally administrated cinnamon extract reduces $\beta$-amyloid oligomerization and corrects cognitive impairment in Alzheimer's disease animal models. PLoS One, 2011, 6(1), e16564. [http://dx.doi.org/10.1371/journal.pone.0016564] [PMID: 21305046]

[50] Conforti, F.; Statti, G.A.; Tundis, R.; Loizzo, M.R.; Menichini, F. In vitro activities of Citrus medica L. cv. Diamante (Diamante citron) relevant to treatment of diabetes and Alzheimer's disease. Phytother. Res., 2007, 21(5), 427-433. [http://dx.doi.org/10.1002/ptr.2077] [PMID: 17236166]

[51] Radenahmad, N.; Saleh, F.; Sawangjaroen, K.; Vongvatcharanon, U.; Subhadhirasakul, P.; Rundorn, W.; Withyachumnarnkul, B.; Connor, J.R. Young coconut juice, a potential therapeutic agent that could significantly reduce some pathologies associated with Alzheimer's disease: Novel findings. Br. J. Nutr., 2011, 105(5), 738-746. [http://dx.doi.org/10.1017/S0007114510004241] [PMID: 21114897]

[52] Fernando, W.M.; Martins, I.J.; Goozee, K.G.; Brennan, C.S.; Jayasena, V.; Martins, R.N. The role of dietary coconut for the prevention and treatment of Alzheimer's disease: Potential mechanisms of action. Br. J. Nutr., 2015, 114(1), 1-14. [http://dx.doi.org/10.1017/S0007114515001452] [PMID: 25997382]

[53] Seo, J.S.; Jung, E.Y.; Kim, J.H.; Lyu, Y.S.; Han, P.L.; Kang, H.W. A modified preparation (LMK03) of the oriental medicine Jangwonhwan reduces Abeta (1-42) level in the brain of Tg-APPswe/PS1dE9 mouse model of Alzheimer disease. J. Ethnopharmacol., 2010, 130(3), 578-585.

[http://dx.doi.org/10.1016/j.jep.2010.05.055] [PMID: 20669372]

[54] Oh, M.H.; Houghton, P.J.; Whang, W.K.; Cho, J.H. Screening of Korean herbal medicines used to improve cognitive function for anticholinesterase activity. Phytomedicine, 2004, 11(6), 544-548. [http://dx.doi.org/10.1016/j.phymed.2004.03.001] [PMID: 15500267]

[55] Singhal, A.K.; Naithani, V.; Bangar, O.P. Medicinal plants with a otential to treat Alzheimer and associated symptoms. Int. J. Nutr. Pharmacol. Neurol. Dis., 2012, 2, 84-91. [http://dx.doi.org/10.4103/2231-0738.95927]

[56] Zhong, S.; Ma, S.; Hong, Z.; Jin, X. Anti-inflammation effect of danggui shaoyao san on Alzheimer's diseases. Zhongguo Zhongyao Zazhi, 2011, 36(22), 3155-3160. [PMID: 22375398]

[57] Hu, Z.Y.; Liu, G.; Cheng, X.R.; Huang, Y.; Yang, S.; Qiao, S.Y.; Sun, L.; Zhou, W.X.; Zhang, Y.X. JD-30, an active fraction extracted from Danggui-Shaoyao-San, decreases $\beta$-amyloid content and deposition, improves LTP reduction and prevents spatial cognition impairment in SAMP8 mice. Exp. Gerontol., 2012, 47(1), 14-22. [http://dx.doi.org/10.1016/j.exger.2011.09.009] [PMID: 22063923]

[58] Hu, Z.Y.; Liu, G.; Yuan, H.; Yang, S.; Zhou, W.X.; Zhang, Y.X.; Qiao, S.Y. Danggui-Shaoyao-San and its active fraction JD-30 improve Abeta-induced spatial recognition deficits in mice. J. Ethnopharmacol., 2010, 128(2), 365-372. [http://dx.doi.org/10.1016/j.jep.2010.01.046] [PMID: 20117199]

[59] Hu, Z.Y.; Liu, G.; Yuan, H.; Yang, S.; Zhou, W.X.; Zhang, Y.X.; Qiao, S.Y. Danggui-Shaoyao-San and its active fraction JD-30 improve Abeta-induced spatial recognition deficits in mice. J. Ethnopharmacol., 2010, 128(2), 365-372. [http://dx.doi.org/10.1016/j.jep.2010.01.046] [PMID: 20117199]

[60] Joshi, H.; Parle, M. Antiamnesic effects of Desmodium gangeticum in mice. Yakugaku Zasshi, 2006, $126(9), 795-804$. [http://dx.doi.org/10.1248/yakushi.126.795] [PMID: 16946593]

[61] Oh, M.H.; Houghton, P.J.; Whang, W.K.; Cho, J.H. Screening of Korean herbal medicines used to improve cognitive function for anticholinesterase activity. Phytomedicine, 2004, 11(6), 544-548. [http://dx.doi.org/10.1016/j.phymed.2004.03.001] [PMID: 15500267]

[62] Lai, C.S.; Yu, M.S.; Yuen, W.H.; So, K.F.; Zee, S.Y.; Chang, R.C. Antagonizing beta-amyloid peptide neurotoxicity of the anti-aging fungus Ganoderma lucidum. Brain Res., 2008, 1190, 215-224. [http://dx.doi.org/10.1016/j.brainres.2007.10.103] [PMID: 18083148]

[63] Patocka, J. Anti-inflammatory triterpenoids from mysterious mushroom Ganoderma lucidum and their potential possibility in modern medicine. Acta Med. (Hradec Kralove), 1999, 42(4), 123-125. [PMID: 10812678]

[64] Huang, Y.; Qi, X.; Guan, Z.; Wang, Y.; Wang, A.; Li, C.; Chi, M. Study on fingerprints correlated with pharmacodynamic of constituents in Herba Erigerontis against neurotoxicity induced by beta-amyloid peptide. Zhongguo Zhongyao Zazhi, 2010, 35(8), $1038-1041$. 
[PMID: 20617689]

[65] Zhu, J.T.; Choi, R.C.; Li, J.; Xie, H.Q.; Bi, C.W.; Cheung, A.W.; Dong, T.T.; Jiang, Z.Y.; Chen, J.J.; Tsim, K.W. Estrogenic and neuroprotective properties of scutellarin from Erigeron breviscapus: A drug against postmenopausal symptoms and Alzheimer's disease. Planta Med., 2009, 75(14), 1489-1493. [http://dx.doi.org/10.1055/s-0029-1185776] [PMID: 19533578]

[66] Lin, P.W.; Chan, W.C.; Ng, B.F.; Lam, L.C. Efficacy of aromatherapy (Lavandula angustifolia) as an intervention for agitated behaviours in Chinese older persons with dementia: a cross-over randomized trial. Int. J. Geriatr. Psychiatry, 2007, 22(5), 405-410. [http://dx.doi.org/10.1002/gps.1688] [PMID: 17342790]

[67] Zali, H.; Zamanian-Azodi, M.; Rezaei Tavirani, M.; Akbar-Zadeh Baghban, A. Protein drug targets of Lavandula angustifolia on treatment of rat Alzheimer's disease.,

[68] Kashani, M.S.; Tavirani, M.R.; Talaei, S.A.; Salami, M. Aqueous extract of lavender (Lavandula angustifolia) improves the spatial performance of a rat model of Alzheimer's disease. Neurosci. Bull., 2011, 27(2), 99-106. [http://dx.doi.org/10.1007/s12264-011-1149-7] [PMID: 21441971]

[69] Lin, P.W.; Chan, W.C.; Ng, B.F.; Lam, L.C. Efficacy of aromatherapy (Lavandula angustifolia) as an intervention for agitated behaviours in Chinese older persons with dementia: A cross-over randomized trial. Int. J. Geriatr. Psychiatry, 2007, 22(5), 405-410. [http://dx.doi.org/10.1002/gps.1688] [PMID: 17342790]

[70] Ho, Y.S.; Yu, M.S.; Yang, X.F.; So, K.F.; Yuen, W.H.; Chang, R.C. Neuroprotective effects of polysaccharides from wolfberry, the fruits of Lycium barbarum, against homocysteine-induced toxicity in rat cortical neurons. J. Alzheimers Dis., 2010, 19(3), 813-827. [http://dx.doi.org/10.3233/JAD-2010-1280] [PMID: 20157238]

[71] Ho, Y.S.; Yu, M.S.; Yik, S.Y.; So, K.F.; Yuen, W.H.; Chang, R.C. Polysaccharides from wolfberry antagonizes glutamate excitotoxicity in rat cortical neurons. Cell. Mol. Neurobiol., 2009, 29(8), 1233-1244. [http://dx.doi.org/10.1007/s10571-009-9419-x] [PMID: 19499323]

[72] Yu, M.S.; Leung, S.K.; Lai, S.W.; Che, C.M.; Zee, S.Y.; So, K.F.; Yuen, W.H.; Chang, R.C. Neuroprotective effects of anti-aging oriental medicine Lycium barbarum against beta-amyloid peptide neurotoxicity. Exp. Gerontol., 2005, 40(8-9), 716-727. [http://dx.doi.org/10.1016/j.exger.2005.06.010] [PMID: 16139464]

[73] Remington, R.; Chan, A.; Lepore, A.; Kotlya, E.; Shea, T.B. Apple juice improved behavioral but not cognitive symptoms in moderate-to-late stage Alzheimer's disease in an open-label pilot study. Am. J. Alzheimers Dis. Other Demen., 2010, 25(4), 367-371. [http://dx.doi.org/10.1177/1533317510363470] [PMID: 20338990]

[74] Rogers, E.J.; Milhalik, S.; Orthiz, D.; Shea, T.B. Apple juice prevents oxidative stress and impaired cognitive performance caused by genetic and dietary deficiencies in mice. J. Nutr. Health Aging, 2004, 8(2), 92-97. [PMID: 14978604]

[75] Shih, P.H.; Chan, Y.C.; Liao, J.W.; Wang, M.F.; Yen, G.C. Antioxidant and cognitive promotion effects of anthocyanin-rich mulberry (Morus atropurpurea L.) on senescence-accelerated mice and prevention of Alzheimer's disease. J. Nutr. Biochem., 2010, 21(7), 598-605. [http://dx.doi.org/10.1016/j.jnutbio.2009.03.008] [PMID: 19443193]

[76] Vasudevan, M.; Parle, M. Antiamnesic potential of Murraya koenigii leaves. Phytother. Res., 2009, 23(3), 308-316. [http://dx.doi.org/10.1002/ptr.2620] [PMID: 18844259]

[77] Yabe, T.; Tuchida, H.; Kiyohara, H.; Takeda, T.; Yamada, H. Induction of NGF synthesis in astrocytes by onjisaponins of Polygala tenuifolia, constituents of kampo (Japanese herbal) medicine, Ninjin-yoei-to. Phytomedicine, 2003, 10(2-3), 106-114. [http://dx.doi.org/10.1078/094471103321659799] [PMID: 12725562]

[78] Huang, Y.; Qi, X.; Guan, Z.; Wang, Y.; Wang, A.; Li, C.; Chi, M. Study on fingerprints correlated with pharmacodynamic of constituents in Herba Erigerontis against neurotoxicity induced by beta-amyloid peptide. Zhongguo Zhongyao Zazhi, 2010, 35(8), 1038-1041. [PMID: 20617689]

[79] Zhou, J.; Zhou, L.; Hou, D.; Tang, J.; Sun, J.; Bondy, S.C. Paeonol increases levels of cortical cytochrome oxidase and vascular actin and improves behavior in a rat model of Alzheimer's disease. Brain Res., 2011, 1388, 141-147. [http://dx.doi.org/10.1016/j.brainres.2011.02.064] [PMID: 21377451]

[80] Fujiwara, H.; Tabuchi, M.; Yamaguchi, T.; Iwasaki, K.; Furukawa, K.; Sekiguchi, K.; Ikarashi, Y.; Kudo, Y.; Higuchi, M.; Saido, T.C.; Maeda, S.; Takashima, A.; Hara, M.; Yaegashi, N.; Kase, Y.; Arai, H. A traditional medicinal herb Paeonia suffruticosa and its active constituent 1,2,3,4,6-penta-O-galloyl-beta-D-glucopyranose have potent anti-aggregation effects on Alzheimer's amyloid beta proteins in vitro and in vivo. J. Neurochem., 2009, 109(6), 1648-1657. [http://dx.doi.org/10.1111/j.1471-4159.2009.06069.x] [PMID: 19457098]

[81] Geng, Y.; Li, C.; Liu, J.; Xing, G.; Zhou, L.; Dong, M.; Li, X.; Niu, Y. Beta-asarone improves cognitive function by suppressing neuronal apoptosis in the beta-amyloid hippocampus injection rats. Biol. Pharm. Bull., 2010, 33(5), 836-843. [http://dx.doi.org/10.1248/bpb.33.836] [PMID: 20460763]

[82] Liu, Z.B.; Niu, W.M.; Yang, X.H.; Wang, Y.; Wang, W.G. Study on perfume stimulating olfaction with volatile oil of Acorus gramineus for treatment of the Alzheimer's disease rat. J. Tradit. Chin. Med., 2010, 30(4), 283-287. [http://dx.doi.org/10.1016/S0254-6272(10)60057-X] [PMID: 21287786]

[83] Perry, E.K.; Pickering, A.T.; Wang, W.W.; Houghton, P.J.; Perry, N.S. Medicinal plants and Alzheimer's disease: From ethnobotany to phytotherapy. J. Pharm. Pharmacol., 1999, 51(5), 527-534. 
[http://dx.doi.org/10.1211/0022357991772808] [PMID: 10411211]

[84] Bonesi, M.; Menichini, F.; Tundis, R.; Loizzo, M.R.; Conforti, F.; Passalacqua, N.G.; Statti, G.A.; Menichini, F. Acetylcholinesterase and butyrylcholinesterase inhibitory activity of Pinus species essential oils and their constituents. J. Enzyme Inhib. Med. Chem., 2010, 25(5), $622-628$. [http://dx.doi.org/10.3109/14756360903389856] [PMID: 20429778]

[85] Zhu, J.T.; Choi, R.C.; Li, J.; Xie, H.Q.; Bi, C.W.; Cheung, A.W.; Dong, T.T.; Jiang, Z.Y.; Chen, J.J.; Tsim, K.W. Estrogenic and neuroprotective properties of scutellarin from Erigeron breviscapus: A drug against postmenopausal symptoms and Alzheimer's disease. Planta Med., 2009, 75(14), 1489-1493. [http://dx.doi.org/10.1055/s-0029-1185776] [PMID: 19533578]

[86] Hage, S.; Kienlen-Campard, P.; Octave, J.N.; Quetin-Leclercq, J. In vitro screening on $\beta$-amyloid peptide production of plants used in traditional medicine for cognitive disorders. J. Ethnopharmacol., 2010, 131(3), 585-591. [http://dx.doi.org/10.1016/j.jep.2010.07.044] [PMID: 20673795]

[87] Choi, S.J.; Lee, J.H.; Heo, H.J.; Cho, H.Y.; Kim, H.K.; Kim, C.J.; Kim, M.O.; Suh, S.H.; Shin, D.H. Punica granatum protects against oxidative stress in PC12 cells and oxidative stress-induced Alzheimer's symptoms in mice. J. Med. Food, 2011, 14(7-8), 695-701. [http://dx.doi.org/10.1089/jmf.2010.1452] [PMID: 21631359]

[88] Lee, C.L.; Pan, T.M. Red mold fermented products and Alzheimer's disease: A review. Appl. Microbiol. Biotechnol., 2011, 91(3), 461-469. [http://dx.doi.org/10.1007/s00253-011-3413-1] [PMID: 21687963]

[89] Lee, C.L.; Kuo, T.F.; Wu, C.L.; Wang, J.J.; Pan, T.M. Red mold rice promotes neuroprotective sAPPalpha secretion instead of Alzheimer's risk factors and amyloid beta expression in hyperlipidemic Abeta40-infused rats. J. Agric. Food Chem., 2010, 58(4), 2230-2238. [http://dx.doi.org/10.1021/jf904027y] [PMID: 20088507]

[90] Lee, C.L.; Wang, J.J.; Pan, T.M. Red mold rice extract represses amyloid beta peptide-induced neurotoxicity via potent synergism of antiinflammatory and antioxidative effect. Appl. Microbiol. Biotechnol., 2008, 79(5), 829-841. [http://dx.doi.org/10.1007/s00253-008-1480-8] [PMID: 18438657]

[91] Lee, C.L.; Kuo, T.F.; Wang, J.J.; Pan, T.M. Red mold rice ameliorates impairment of memory and learning ability in intracerebroventricular amyloid beta-infused rat by repressing amyloid beta accumulation. J. Neurosci. Res., 2007, 85(14), 3171-3182. [http://dx.doi.org/10.1002/jnr.21428] [PMID: 17663476]

[92] Mo, G.L.; Li, Y.; Du, R.H.; Dai, D.Z.; Cong, X.D.; Dai, Y. Isoproterenol induced stressful reactions in the brain are characterized by inflammation due to activation of NADPH oxidase and ER stress: attenuated by Apocynin, Rehmannia complex and Triterpene acids. Neurochem. Res., 2014, 39(4), 719-730. [http://dx.doi.org/10.1007/s11064-014-1260-z] [PMID: 24570113]

[93] Liu, J.P.; Feng, L.; Zhang, M.H.; Ma, D.Y.; Wang, S.Y.; Gu, J.; Fu, Q.; Qu, R.; Ma, S.P. Neuroprotective effect of Liuwei Dihuang decoction on cognition deficits of diabetic encephalopathy in streptozotocin-induced diabetic rat. J. Ethnopharmacol., 2013, 150(1), 371-381. [http://dx.doi.org/10.1016/j.jep.2013.09.003] [PMID: 24041458]

[94] Lee, B.; Shim, I.; Lee, H.; Hahm, D.H. Rehmannia glutinosa ameliorates scopolamine-induced learning and memory impairment in rats. $J$. Microbiol. Biotechnol., 2011, 21(8), 874-883. [http://dx.doi.org/10.4014/jmb.1104.04012] [PMID: 21876380]

[95] Liang, J.H.; Du, J.; Xu, L.D.; Jiang, T.; Hao, S.; Bi, J.; Jiang, B. Catalpol protects primary cultured cortical neurons induced by Abeta(1-42) through a mitochondrial-dependent caspase pathway. Neurochem. Int., 2009, 55(8), 741-746. [http://dx.doi.org/10.1016/j.neuint.2009.07.004] [PMID: 19631247]

[96] Jiang, B.; Du, J.; Liu, J.H.; Bao, Y.M.; An, L.J. Catalpol attenuates the neurotoxicity induced by beta-amyloid(1-42) in cortical neuron-glia cultures. Brain Res., 2008, 1188, 139-147. [http://dx.doi.org/10.1016/j.brainres.2007.07.105] [PMID: 18022141]

[97] Yu, H.; Oh-Hashi, K.; Tanaka, T.; Sai, A.; Inoue, M.; Hirata, Y.; Kiuchi, K. Rehmannia glutinosa induces glial cell line-derived neurotrophic factor gene expression in astroglial cells via cPKC and ERK1/2 pathways independently. Pharmacol. Res., 2006, 54(1), 39-45. [http://dx.doi.org/10.1016/j.phrs.2006.01.014] [PMID: 16600621]

[98] Cui, Y.; Yan, Z.H.; Hou, S.L.; Chang, Z.F. Intelligence enhancement of radix Rehmanniae praeparata and some comments on its research. Zhongguo Zhongyao Zazhi, 2002, 27(6), 404-406, 456. [PMID: 12817566]

[99] Loizzo, M.R.; Tundis, R.; Conforti, F.; Menichini, F.; Bonesi, M.; Nadjafi, F.; Frega, N.G.; Menichini, F. Salvia leriifolia Benth (Lamiaceae) extract demonstrates in vitro antioxidant properties and cholinesterase inhibitory activity. Nutr. Res., 2010, 30(12), 823-830. [http://dx.doi.org/10.1016/j.nutres.2010.09.016] [PMID: 21147365]

[100] Loizzo, M.R.; Menichini, F.; Tundis, R.; Bonesi, M.; Conforti, F.; Nadjafi, F.; Statti, G.A.; Frega, N.G.; Menichini, F. In vitro biological activity of Salvia leriifolia benth essential oil relevant to the treatment of Alzheimer's disease. J. Oleo Sci., 2009, 58(8), 443-446. [http://dx.doi.org/10.5650/jos.58.443] [PMID: 19584571]

[101] Miroddi, M.; Navarra, M.; Quattropani, M.C.; Calapai, F.; Gangemi, S.; Calapai, G. Systematic review of clinical trials assessing pharmacological properties of Salvia species on memory, cognitive impairment and Alzheimer's disease. CNS Neurosci. Ther., 2014, 20(6), 485-495.

[http://dx.doi.org/10.1111/cns.12270] [PMID: 24836739] 
[102] Vladimir-Knežević, S.; Blažeković, B.; Kindl, M.; Vladić, J.; Lower-Nedza, A.D.; Brantner, A.H. Acetylcholinesterase inhibitory, antioxidant and phytochemical properties of selected medicinal plants of the Lamiaceae family. Molecules, 2014, 19(1), $767-782$. [http://dx.doi.org/10.3390/molecules19010767] [PMID: 24413832]

[103] Russo, P.; Frustaci, A.; Del Bufalo, A.; Fini, M.; Cesario, A. From traditional European medicine to discovery of new drug candidates for the treatment of dementia and Alzheimer's disease: acetylcholinesterase inhibitors. Curr. Med. Chem., 2013, $20(8), 976-983$. [PMID: 23210783]

[104] Akhondzadeh, S.; Noroozian, M.; Mohammadi, M.; Ohadinia, S.; Jamshidi, A.H.; Khani, M. Salvia officinalis extract in the treatment of patients with mild to moderate Alzheimer's disease: a double blind, randomized and placebo-controlled trial. J. Clin. Pharm. Ther., 2003, 28(1), 53-59. [http://dx.doi.org/10.1046/j.1365-2710.2003.00463.x] [PMID: 12605619]

[105] Iuvone, T.; De Filippis, D.; Esposito, G.; D’Amico, A.; Izzo, A.A. The spice sage and its active ingredient rosmarinic acid protect PC12 cells from amyloid-beta peptide-induced neurotoxicity. J. Pharmacol. Exp. Ther., 2006, 317(3), 1143-1149. [http://dx.doi.org/10.1124/jpet.105.099317] [PMID: 16495207]

[106] Marcelo, F.; Dias, C.; Martins, A.; Madeira, P.J.; Jorge, T.; Florêncio, M.H.; Cañada, F.J.; Cabrita, E.J.; Jiménez-Barbero, J.; Rauter, A.P. Molecular recognition of rosmarinic acid from Salvia sclareoides extracts by acetylcholinesterase: A new binding site detected by NMR spectroscopy. Chemistry, 2013, 19(21), 6641-6649. [http://dx.doi.org/10.1002/chem.201203966] [PMID: 23536497]

[107] Airoldi, C.; Sironi, E.; Dias, C.; Marcelo, F.; Martins, A.; Rauter, A.P.; Nicotra, F.; Jimenez-Barbero, J. Natural compounds against Alzheimer's disease: molecular recognition of A $\beta 1-42$ peptide by Salvia sclareoides extract and its major component, rosmarinic acid, as investigated by NMR. Chem. Asian J., 2013, 8(3), 596-602. [http://dx.doi.org/10.1002/asia.201201063] [PMID: 23303581]

[108] Rauter, A.P.; Branco, I.; Lopes, R.G.; Justino, J.; Silva, F.V.; Noronha, J.P.; Cabrita, E.J.; Brouard, I.; Bermejo, J. A new lupene triterpenetriol and anticholinesterase activity of Salvia sclareoides. Fitoterapia, 2007, 78(7-8), 474-481. [http://dx.doi.org/10.1016/j.fitote.2007.02.013] [PMID: 17570616]

[109] Chattipakorn, S.; Pongpanparadorn, A.; Pratchayasakul, W.; Pongchaidacha, A.; Ingkaninan, K.; Chattipakorn, N. Tabernaemontana divaricata extract inhibits neuronal acetylcholinesterase activity in rats. J. Ethnopharmacol., 2007, 110(1), 61-68. [http://dx.doi.org/10.1016/j.jep.2006.09.007] [PMID: 17023131]

[110] Vasudevan, M.; Parle, M. Pharmacological actions of Thespesia populnea relevant to Alzheimer's disease. Phytomedicine, 2006, 13(9-10), $677-687$.

[http://dx.doi.org/10.1016/j.phymed.2006.01.007] [PMID: 16860552]

[111] Guo, Q.; Ma, X.; Wei, S.; Qiu, D.; Wilson, I.W.; Wu, P.; Tang, Q.; Liu, L.; Dong, S.; Zu, W. De novo transcriptome sequencing and digital gene expression analysis predict biosynthetic pathway of rhynchophylline and isorhynchophylline from Uncaria rhynchophylla, a non-model plant with potent anti-alzheimer's properties. BMC Genomics, 2014, 15, 676. [http://dx.doi.org/10.1186/1471-2164-15-676] [PMID: 25112168]

[112] Xian, Y.F.; Mao, Q.Q.; Wu, J.C.; Su, Z.R.; Chen, J.N.; Lai, X.P.; Ip, S.P.; Lin, Z.X. Isorhynchophylline treatment improves the amyloid- $\beta$ induced cognitive impairment in rats via inhibition of neuronal apoptosis and tau protein hyperphosphorylation. J. Alzheimers Dis., 2014, $39(2), 331-346$.

[PMID: 24164737]

[113] Xian, Y.F.; Lin, Z.X.; Zhao, M.; Mao, Q.Q.; Ip, S.P.; Che, C.T. Uncaria rhynchophylla ameliorates cognitive deficits induced by D-galactose in mice. Planta Med., 2011, 77(18), 1977-1983.

[http://dx.doi.org/10.1055/s-0031-1280125] [PMID: 21858756]

[114] Wu, T.Y.; Chen, C.P.; Jinn, T.R. Traditional Chinese medicines and Alzheimer's disease. Taiwan. J. Obstet. Gynecol., $2011,50(2), 131-135$. [corrected to Chen, Chih-Ping]. [http://dx.doi.org/10.1016/j.tjog.2011.04.004] [PMID: 21791295]

[115] Fujiwara, H.; Iwasaki, K.; Furukawa, K.; Seki, T.; He, M.; Maruyama, M.; Tomita, N.; Kudo, Y.; Higuchi, M.; Saido, T.C.; Maeda, S.; Takashima, A.; Hara, M.; Ohizumi, Y.; Arai, H. Uncaria rhynchophylla, a Chinese medicinal herb, has potent antiaggregation effects on Alzheimer's beta-amyloid proteins. J. Neurosci. Res., 2006, 84(2), 427-433.

[http://dx.doi.org/10.1002/jnr.20891] [PMID: 16676329]

[116] Wang, Q.; Wang, C.; Shu, Z.; Chan, K.; Huang, S.; Li, Y.; Xiao, Y.; Wu, L.; Kuang, H.; Sun, X. Valeriana amurensis improves Amyloid-beta 1-42 induced cognitive deficit by enhancing cerebral cholinergic function and protecting the brain neurons from apoptosis in mice. $J$. Ethnopharmacol., 2014, 153(2), 318-325.

[http://dx.doi.org/10.1016/j.jep.2013.11.017] [PMID: 24269774]

[117] Wang, Q.; Wang, C.; Zuo, Y.; Wang, Z.; Yang, B.; Kuang, H. Compounds from the roots and rhizomes of Valeriana amurensis protect against neurotoxicity in PC12 cells. Molecules, 2012, 17(12), 15013-15021. [http://dx.doi.org/10.3390/molecules171215013] [PMID: 23250029]

[118] Zhang, Z.L.; Zuo, Y.M.; Wang, Q.H.; Xiao, H.B.; Kuang, H.X. Effects of Valeriana amurensis on the expressions of iNOS, COX-2 and IkappaCB-alpha in Alzheimer's disease model rat's brain. Zhong Yao Cai, 2010, 33(4), 581-583. [PMID: 20845789] 
[119] Zuo, Y.M.; Zhang, Z.L.; Wang, Q.H.; Xie, N.; Kuang, H.X. Effects of Valeriana amurensis on the expressions of beta-APP, Abeta(1-40) and caspase-3 in Alzheimer's disease model rat's brain. Zhong Yao Cai, 2010, 33(2), 233-236. [PMID: 20575418]

[120] Jeong, H.Y.; Kim, J.Y.; Lee, H.K.; Ha, T.; Song, K.S.; Bae, K.; Seong, Y.H. Leaf and stem of Vitis amurensis and its active components protect against amyloid $\beta$ protein (25-35)-induced neurotoxicity. Arch. Pharm. Res., 2010, 33(10), 1655-1664. [http://dx.doi.org/10.1007/s12272-010-1015-6] [PMID: 21052941]

[121] Sehgal, N.; Gupta, A.; Valli, R.K.; Joshi, S.D.; Mills, J.T.; Hamel, E.; Khanna, P.; Jain, S.C.; Thakur, S.S.; Ravindranath, V. Withania somnifera reverses Alzheimer's disease pathology by enhancing low-density lipoprotein receptor-related protein in liver. Proc. Natl. Acad. Sci. USA, 2012, 109(9), 3510-3515. [http://dx.doi.org/10.1073/pnas.1112209109] [PMID: 22308347]

[122] Kubota, K.; Nogami, A.; Takasaki, K.; Katsurabayashi, S.; Mishima, K.; Fujiwara, M.; Iwasaki, K. Pharmacological study of the amerliorative effects of Yokukansan on memory impairment and the behavioral and psychological symptoms of dementia in AD models. Nippon Yakurigaku Zasshi, 2014, 143(3), 110-114. [http://dx.doi.org/10.1254/fpj.143.110] [PMID: 24614632]

[123] Uchida, N.; Takasaki, K.; Sakata, Y.; Nogami, A.; Oishi, H.; Watanabe, T.; Shindo, T.; Egashira, N.; Kubota, K.; Katsurabayashi, S.; Mishima, K.; Fujiwara, M.; Nishimura, R.; Iwasaki, K. Cholinergic involvement and synaptic dynamin 1 expression in Yokukansan-mediated improvement of spatial memory in a rat model of early Alzheimer's disease. Phytother. Res., 2013, 27(7), 966-972. [http://dx.doi.org/10.1002/ptr.4818] [PMID: 22888033]

[124] Nishiyama, N.; Takeshita, M.; Tanaka, K.; Miyao, M.; Mizuno, Y. [A case of severe hypokalemia caused by a Chinese herbal remedy (Yokukansan) in an 81-year-old woman with dementia]. Nippon Ronen Igakkai Zasshi, 2011, 48(5), 553-557. [A case of severe hypokalemia caused by a Chinese herbal remedy (Yokukansan) in an 81-year-old woman with dementia]. [in Japanese]. [http://dx.doi.org/10.3143/geriatrics.48.553] [PMID: 22323035]

[125] Yamada, M.; Hayashida, M.; Zhao, Q.; Shibahara, N.; Tanaka, K.; Miyata, T.; Matsumoto, K. Ameliorative effects of yokukansan on learning and memory deficits in olfactory bulbectomized mice. J. Ethnopharmacol., 2011, 135(3), 737-746. [http://dx.doi.org/10.1016/j.jep.2011.04.010] [PMID: 21513784]

[126] Fujiwara, H.; Takayama, S.; Iwasaki, K.; Tabuchi, M.; Yamaguchi, T.; Sekiguchi, K.; Ikarashi, Y.; Kudo, Y.; Kase, Y.; Arai, H.; Yaegashi, N. Yokukansan, a traditional Japanese medicine, ameliorates memory disturbance and abnormal social interaction with anti-aggregation effect of cerebral amyloid $\beta$ proteins in amyloid precursor protein transgenic mice. Neuroscience, 2011, 180, 305-313. [http://dx.doi.org/10.1016/j.neuroscience.2011.01.064] [PMID: 21303686]

[127] Ali, S.K.; Hamed, A.R.; Soltan, M.M.; Hegazy, U.M.; Elgorashi, E.E.; El-Garf, I.A.; Hussein, A.A. In-vitro evaluation of selected Egyptian traditional herbal medicines for treatment of Alzheimer disease. BMC Complement. Altern. Med., 2013, $13,121$. [http://dx.doi.org/10.1186/1472-6882-13-121] [PMID: 23721591]

[128] Shishodia, S.; Sethi, G.; Aggarwal, B.B. Curcumin: Getting back to the roots. Ann. N. Y. Acad. Sci., 2005, 1056, $206-217$. [http://dx.doi.org/10.1196/annals.1352.010] [PMID: 16387689]

\section{(C) 2018 Kalász et al.}

This is an open access article distributed under the terms of the Creative Commons Attribution 4. 0 International Public License (CC-BY 4. 0), a copy of which is available at: https:/creativecommons. org/licenses/by/4. 0/legalcode. This license permits unrestricted use, distribution, and reproduction in any medium, provided the original author and source are credited. 